\title{
PREDATION ON THE TOXIC ZOANTHID Palythoa caribaeorum BY REEF FISHES IN THE ABROLHOS BANK, EASTERN BRAZIL
}

\author{
Ronaldo Bastos Francini-Filho, ${ }^{1,2}{ }^{*}$ and Rodrigo Leão de Moura $^{2}$ \\ ${ }^{1}$ Universidade Estadual da Paraíba - Departamento de Biologia, Centro de Ciências Biológicas e da Saúde \\ (Avenida das Baraúnas, 351, 58109-753 Campina Grande, PB, Brasil) \\ *Corresponding author e-mail: rofilho@yahoo.com \\ ${ }^{2}$ Marine Program, Conservation International Brasil \\ (Rua das Palmeiras, 451, 45900-000 Caravelas, BA, Brasil) \\ E-mail: r.moura@conservation.org.br
}

Palythoa caribaeorum is a common zoanthid that occurs on shallow hard bottoms throughout the Western Atlantic from southern Florida to southern Brazil. It is characterized by possessing the highest growth rate among the anthozoans (up to $4 \mathrm{~mm} . / \mathrm{day}^{-1}$ ) and the strongest non-proteinaceous marine toxin known to date, the palytoxin (MOORE; SCHEUER, 1971; SUCHANEK; GREEN, 1981). These characteristics make $P$. caribaeorum an aggressive competitor for space as it kills or inhibit the growth of nearly all other sessile reef invertebrates, including corals, fire-corals, sponges and gorgonians (SUCHANEK; GREEN, 1981; ACOSTA, 2001). Thus far, only a few invertebrates and four reef fish species (Chaetodon capistratus, C. sedentarius, Sphoeroides spengleri and Stegastes sp.) have been recorded preying upon $P$. caribaeorum in the Caribbean (SUCHANEK; GREEN, 1981; GLEIBS; MEBS, 1998). The only other vertebrate known to prey upon $P$. caribaeorum is the hawksbill turtle, Eretmochelys imbricata, recently recorded feeding on this zoanthid in rocky reefs off Southeastern Brazil (STAMPAR et al., 2007).

In this note we record the predation of $P$. caribaeorum by four reef fish species (one pomacentrid, Abudefduf saxatilis, one monacanthid, Cantherhines macrocerus, and two pomacanthids, Pomacanthus arcuatus and P. paru) in the Abrolhos Bank, eastern Brazil. The study region covers the largest and richest coral reefs in the South Atlantic, where $P$. caribaeorum occupies extensive areas of shallow rocky reefs and tops of coralline pinnacles (see Francini-Filho; Moura, 2008 and Francini-Filho et al., 2008 for maps and a detailed description of the region).
Underwater observations were undertaken at three sites (Portinho Norte, within the Abrolhos Archipelago, Parcel dos Abrolhos and Arenguera) between 2005 and 2007. After zoanthid predation by fish was noticed fortuitously in 2005, predation events were systematically recorded during the summer (February-March) of two consecutive years (20062007), by crossing the same area of the reef, totaling about $10 \mathrm{~h}$ of underwater observations per site per year.

Abudefduf saxatilis is a small sized (about 20 cm max. total length, TL) omnivorous fish that ranks among the three most abundant reef fish species at the sites studied (MOURA; FRANCINI-FILHO, 2006), having accounted for most records of zoanthid predation $(\mathrm{n}=28)$. Cantherhines macrocerus accounted for 14 zoanthid predation events, while $P$. paru and $P$. arcuatus accounted for 8 and 4 of such records, respectively (Table 1 ). Although $P$. arcuatus and $P$. paru are not numerically dominant they are large-sized (ca. $50 \mathrm{~cm}$ max. TL) and conspicuous elements of the reef fish assemblage, composing 5.1 and $4.7 \%$, respectively, of the total reef fish biomass in the study region (FRANCINI-FILHO; MOURA, 2008). Cantherhines macrocerus is also relatively large (about $45 \mathrm{~cm}$ max. TL), but is much rarer (< $0.1 \%$ of reef fish biomass). Predation was undertaken by groups of 3-8 A. saxatilis individuals (Fig. 1) and by single individuals or pairs of $C$. macrocerus, $P$. arcuatus and $P$. paru. These latter three species took only a single or a few bites and then moved away from the zoanthid colonies, while groups of $A$. saxatilis took repeated and overlapping bites from the same colonies, causing larger lesions (Fig. 1). Predation was always concentrated on tissue that was previously undamaged and not bleached nor diseased (see ACOSTA, 2001).

Table 1. Number of records of zoanthid (Palythoa caribaeorum) predation by reef fishes at three sites within the Abrolhos Bank. Sampling sites: PAAB - Parcel dos Abrolhos, AREN - Arenguera and PNOR - Portinho Norte (within the Abrolhos Archipelago).

\begin{tabular}{lcccc}
\hline \hline \multirow{2}{*}{ Fish species } & \multicolumn{3}{c}{ Sampling site } & Total \\
\cline { 2 - 4 } & PAAB & AREN & PNOR & $\mathbf{2 8}$ \\
Abudefduf saxatilis & 0 & 2 & 26 & $\mathbf{1 4}$ \\
Cantherhines macrocerus & 2 & 8 & 4 & $\mathbf{8}$ \\
Pomacanthus paru & 2 & 6 & 0 & $\mathbf{4}$ \\
Pomacanthus arcuatus & 1 & 3 & 0 & \\
\hline
\end{tabular}



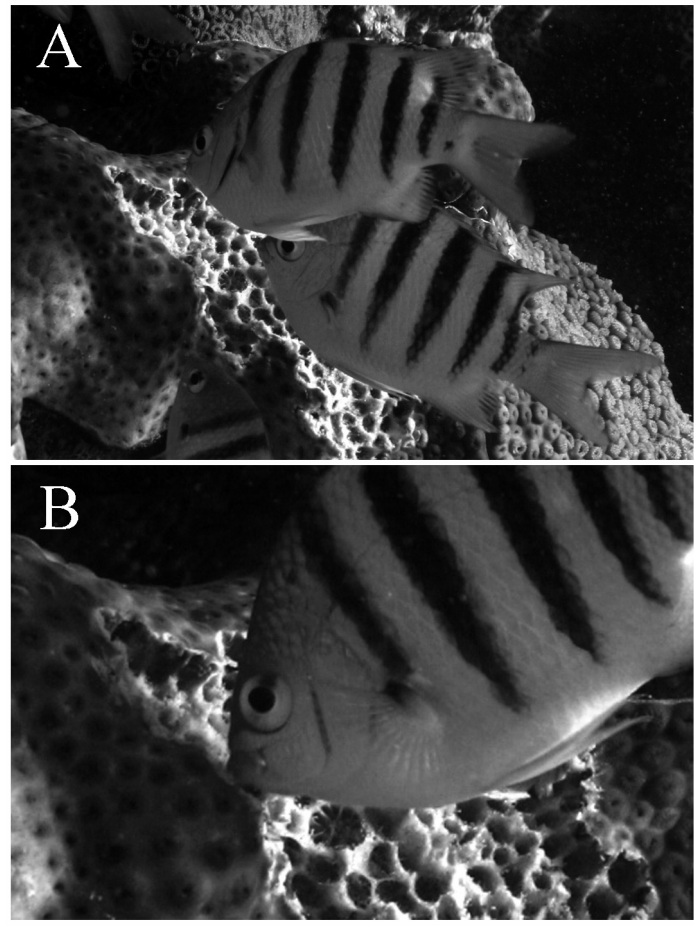

Fig. 1. (A) A group of Abudefduf saxatilis preying upon Palythoa caribaeorum and (B) a close up view of an $A$. saxatilis individual preying upon $P$. caribaeorum. Photos by R.B. Francini-Filho.

Stampar et al. (2007) suggest that hawksbill turtles may consume $P$. caribaeorum when other preferred food resources are scarce. However, this seems not to be the case of reef fishes in the Abrolhos Bank, since other food items commonly ingested by $A$. saxatilis, C. macrocerus, $P$. arcuatus and $P$. paru (RANDALL, 1967; HOURIGAN et al., 1989), including algae, sponges and several other benthic invertebrates, were also available at the study site. Instead, these reef fishes may consume $P$. caribaeorum because of its nutritional value and/or to store palytoxin in their tissue to protect themselves from potential predators (MOORE; SCHEUER, 1971). Pomacanthus arcuatus, $P$. paru and C. macrocerus are known to feed on other highly toxic benthic invertebrates, particularly sponges and gorgonians, as well (RANDALL, 1967; HOURIGAN et al., 1989), while A. saxatilis may consume large amounts of the zoanthid Zoanthus sociatus (RANDALL, 1967) which also contains palytoxin (GLEIBS; MEBS, 1998). Thus, these fishes are clearly adapted for ingesting a wide range of chemically defended sessile organisms, which are probably unsuitable as food resources for other reef organisms.

The high frequency of zoanthid predation events by $A$. saxatilis, coupled with its small size and high abundance in the study area may provide clues for the investigation of important food web links. Palytoxin recorded in the tissue of several marine organisms, most of them not known to prey upon $P$. caribaeorum (GLEIBS; MEBS, 1999), has been attributed to the fact that it may be transported and accumulated in the food chain (GLEIBS; MEBS, 1998, 1999). Thus, because A. saxatilis is abundant throughout its range and an important prey of several large sized fishes such as snappers (family Lutjanidae) and groupers (family Serranidae) (e.g. RANDALL, 1967), it may represent a major link for the entrance of palytoxin in the Atlantic Ocean reefs' food web.

Suchanek and Green (1981) state that predation may not be a major factor controlling the abundance of $P$. caribaeorum in St. Croix, US Virgin Islands, since they recorded only one occasional predator, the fireworm Hermodice carunculata. However, results from this study indicate that the number of organisms capable of ingesting $P$. caribaeorum is greater than had previously been thought. Predation has also been historically disregarded as an important process controlling the distribution and abundance of scleractinian corals. However, recent reviews indicate that at least 128 fish species (including $P$. arcuatus and $C$. macrocerus) of 11 different families are known to feed on live corals, several of which have been recognized as able to modify the distribution and abundance of their coral prey (COLE et al., 2008). Thus, similarly to corallivory, predation by fishes may represent an important although hitherto overlooked process affecting the abundance of $P$. caribaeorum, also possibly representing a major path for the entrance of palytoxin in the food web.

\section{ACKNOWLEDGMENTS}

We wish to thank P.Y.G. Sumida for reviewing the manuscript. G. F. Dutra and L. Kaufman for essential advice. G. Fiuza-Lima, D. L. Araújo, C. M. Ferreira, E. Coni, E. Marocci, P. Meirelles, R. M. Reis and I. Cruz for field assistance. Parque Nacional Marinho de Abrolhos/IBAMA (through M. Lourenço) for research permits. Financial support was provided by Conservation International Brazil. This is contribution number eleven of the Marine Management Areas Science Program, Brazil Node.

\section{REFERENCES}

ACOSTA, A. Disease in Zoanthids: Dynamics in space and time. Hydrobiologia, v. 460, p. 113-130, 2001.

COLE, A. J.; PRATCHETT, M. S.; JONES G. P. Diversity and functional importance of coral-feeding fishes on tropical coral reefs. Fish Fish., v. 9, p. 286-307, 2008. 
FRANCINI-FILHO, R. B.; MOURA, R. L. Dynamics of fish assemblages on coral reefs subjected to different management regimes in the Abrolhos Bank, eastern Brazil. Aquat. Conserv. mar. Freshwat. Ecosys., v. 18, p. 1166-1179, 2008.

FRANCINI-FILHO, R. B.; MOURA, R. L.; THOMPSON, F. L.; REIS, R. D.; KAUFMAN, L.; KIKUCHI, R. K. P.; LEÃO, Z. M. A. N. Diseases leading to accelerated decline of reef corals in the largest South Atlantic reef complex (Abrolhos Bank, eastern Brazil). Mar. Pollut. Bull., v. 56, n. 5, p. 1008-1014, 2008.

GLEIBS, S.; MEBS, D. Sequestration of a marine toxin. Coral Reefs, v. 17, n. 4, p. 338, 1998.

GLEIBS, S.; MEBS, D. Distribution and sequestration of palytoxin in coral reef animals. Toxicon, v. 37, n. 11, p. 1521-1527, 1999.

HOURIGAN, T. F.; STANTON, F. G.; MOTTA, P. J.; KELLEY, C. D.; CARLSON, B. The feeding ecology of three species of Caribbean angelfishes (family Pomacanthidae). Environ. Biol. Fishes, v. 24, n. 2, p. 105-116, 1989.

MOORE, R. E.; SCHEUER, P. J. Palytoxin: A new marine toxin from a coelenterate. Science, v. 172, p. 495-496, 1971.
MOURA, R. L.; FRANCINI-FILHO, R. B. Reef and shore fishes of the Abrolhos Region, Brazil. In: DUTRA, G. F; ALEN, G. R.; WERNER, T.; MCKENNA, S. A. (Ed.). A rapid marine biodiversity assessment of the Abrolhos Bank, Bahia, Brazil. RAP Bulletin of Biological Assessment 38. Washington DC: Conservation International, 2006. p. 40-55.

RANDALL, J. E. Food habits of reef fishes of the West Indies. Stud. trop. Oceanogr., v 5, p. 665-847, 1967.

STAMPAR, S. N.; SILVA, P. F.; LUIZ JR, O. J. Predation on the zoanthid Palythoa caribaeorum (Anthozoa, Cnidaria) by a Hawksbill turtle (Eretmochelys imbricata) in Southeastern Brazil. Mar. Turtle Newslet., v. 117, p. 3-5, 2007.

SUCHANEK, T. H.; GREEN, D. J. Interespecific competition between Palythoa caribaeorum and other sessile invertebrates on St. Croix reefs, U.S. Virgin Islands. In: INT. CORAL REEF SYMP., 4 . Proc. ... v. 2, 1981. p. 679-684.

(Manuscript received 24 March 2009; revised 21 September 2009; accepted 01 October 2009) 